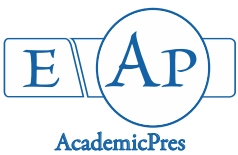

Khoshkharam M et al. (2021)

Notulae Scientia Biologicae

Volume 13, Issue 2, Article number 10949

DOI: $10.15835 / \mathrm{nsb} 13210949$

Research Article

\title{
The effects of methanol and amino acid glycine betaine on qualitative characteristics and yield of sugar beet (Beta vulgaris L.) cultivars
}

\section{Mehdi KHOSHKHARAM ${ }^{1 *}$, Mohamad H. SHAHRAJABIAN ${ }^{2}$, Mehrdad ESFANDIARY3}

\author{
${ }^{1}$ Islamic Azad University, Department of Agronomy and Plant Breeding, Isfahan (Khorasgan) Branch, Isfahan, \\ Iran; mehdi.khoshkharam@gmail.com (*corresponding author) \\ ${ }^{2}$ Chinese Academy of Agricultural Sciences, Biotechnology Research Institute, Beijing 100081, \\ China; hesamshahrajabian@gmail.com \\ ${ }^{3}$ Islamic Azad University, Department of Agronomy and Plant Breeding, Karaj Branch, Alborz, \\ Iran; mehrdad.esfandiary@gmail.com
}

\begin{abstract}
In order to investigate the effects of methanol and glycine betaine application on quality traits and yield of different fodder beet cultivars, the experiment was performed as a combined split-factorial design based on randomized complete block design with 3 replications in two years in Isfahan, Iran. The concentrations of methanol in 3 levels (control, 15 and 30\% v/v methanol) were considered as the first treatment, the concentrations of glycine betaine in 2 levels (control and $4 \mathrm{~g}$ per liter) as the second treatment and different cultivars ('Sentinel', 'Drafter', 'Rivolta', 'Elanta', 'Rasta', and 'Qualita') were considered as the factorial. Foliar spraying was performed at three intervals every two weeks. The results showed that the methanol spraying affected on root yield, sugar, potassium and sodium content, catalase enzyme activity, superoxide dismutase, rubisco, and malondialdehyde significantly. Glycine betaine foliar application showed significant differences in root yield, sugar, potassium and sodium content, enzyme catalase activity, superoxide dismutase, rubisco, and malondialdehyde. Based on the results, the utilization of methanol and glycine betaine caused quality improvement of the sugar beet under similar conditions of the present experiment.
\end{abstract}

Keywords: catalase; malondialdehyde; nitrate reductase; rubisco; superoxide dismutase

\section{Introduction}

Most parts of the world are exposed to drought, and water scarcity is one of the critical issues leading to reduced crop yields. Beet cultivars have shown significant differences in terms of yield under different environmental conditions, which indicates their adaptability to environmental stresses (Albayrak and Camas, 2007). Increasing the concentration of carbon dioxide due to reduced light respiration and counteracting the destructive effects of environmental stress can improve plant performance by preserving or increasing dry matter. One way to increase the concentration of carbon dioxide and reduce the destructive effects of drought stress on plants is to apply the alcoholic compounds and glycine betaine (GB) amino acid. Methanol is the simplest compound produced in the plant (Felix et al., 2019). Methanol produces carbon dioxide in the leaves

Received: 10 Apr 2021. Received in revised form: 08 May 2021. Accepted: 24 May 2021. Published online: 25 May 2021. From Volume 13, Issue 1, 2021, Notulae Scientia Biologicae journal uses article numbers in place of the traditional method of continuous pagination through the volume. The journal will continue to appear quarterly, as before, with four annual numbers. 
and escalates photosynthesis, so it can be used as a carbon source (Saneienejad et al., 2019). Methanol also controls the growth and development of plants by affecting the intracellular transport of macromolecules (Dorokhov et al., 2018). It has been indicated that when the cotton treated with exogenous methanol, the Rubisco activities increased by above $60 \%$, and also the net photosynthesis rate and intercellular $\mathrm{CO}_{2}$ concentration were increased. Many studies have shown the role of methanol as a biochemical by-product as a signal molecule in plant-plant communication, but studies in the last decade have revealed that it has participated in metabolic biochemical processes during growth and development. Methanol emissions escalate in response to mechanical wounding or other stresses due to damage of the cell wall, which is the main source of methanol production. The insoluble compounds of electrical chargeless such as alcohols, aldehydes, and sugars easily penetrate and pass-through protoplasmic membranes. Also, methanol passes through by diffusion from the membrane of the plant cells (Reinhold and Kaplan, 1984). Under drought stress condition, methanol spraying can prevent their biomass reduction (Dorokhov et al., 2018). However, methanol spraying has an negative effect on plants that do not have moisture restrictions (Nadali et al., 2010; Rehman and Khalil, 2018).

The toxicity of methanol solutions may be related to the ability to oxidize it. Methanol in some plants could be oxidized, immediately, to $\mathrm{CO}_{2}$, formaldehyde, and formic acid (Fall and Benson, 1996). The intermediate formaldehyde represents a reactive electrophilic species with high toxicity that is rapidly detoxified by a pathway involving three key enzymes: (1) NAD dependent formaldehyde dehydrogenase (FALD), (2) thiolesterase S-formylglutathione (FGH), and (3) NAD-dependent formate dehydrogenase (FDH), which oxidizes the formate to $\mathrm{CO}_{2}$ ((Haslam et al., 2002; Kordic et al., 2002; Achkor et al., 2003). According to Demmers-Derks et al. (1996), increasing dioxide carbon content will not essentially result in increased sugar content in plants, because there is a negative correlation between sugar content and root yield. Excessive synthesis of methanol has been observed to lead to the shortening of tobacco (Hasunuma et al., 2004; Sheshukova et al., 2017). Therefore, methanol seems to be essential for balance in plant growth and development. Methanol application on $\mathrm{C}_{3}$ plants can compensate for part of the photosynthetic carbon losses, so increases the efficiency of photosynthesis (McGiffen and Manthey, 1996; Behrouzyar and Yarnia, 2016; Rehman and Khalil, 2018). Methanol is oxidized in the form of aldehyde and carbon dioxide in the plant and is synthesized as amino acids (serine and methionine) and carbohydrates in various tissues of $\mathrm{C}_{3}$ plants. Methanol-treated plants can increase their net assimilation rate (Nonomura and Benson, 1992). Exogenous methanol accelerates the production of sugars and amino acids and increases the production of dry matter, leaf photosynthesis, grain yield, and also reduces the water use efficiency on the plant (Valizadeh-Kamran et al., 2019). Increasing the crop growth rate after methanol spraying is due to increasing the concentration of carbon dioxide in the leaves and using methanol as a direct source for the synthesis of serine amino acids besides reducing carbon loss through light respiration (Dorokhov et al., 2018). Glycine betaine plays an important role in regulating cellular osmosis, maintaining organs (mitochondria, chloroplasts), and water efficiency in plants under water deficit (Ashraf and Foolad, 2007; Kurepin et al., 2015). The exogenous glycine betaine has been proven to improve growth traits and plant performance under drought stress (Khan et al., 2015; Joshi et al., 2016).

Nawaz and Wang (2020) report drought stress decreased photosynthetic pigments and increased reactive oxygen species, lipid peroxidation, osmolytes, and antioxidants in the plan. Nonetheless, exogenous GB alone improved drought tolerance. The maximum decrease in malondialdehyde, and increase in soluble sugars, chlorophyll contents, and superoxide dismutase, catalase, peroxidase was recorded when GB was applied alone under drought. In many plants, the accumulation of GB is lower than sufficient to modify the adverse effects of dehydration caused by various environmental stresses. Exogenous application of GB could help diminish the adverse effects of environmental stresses (Mäkelä, 2004; Ashraf and Foolad, 2007). Sprayed GB is immediately absorbed by plant tissues and is readily translocated to the roots, meristems, and leaves (Mäkelä et al., 2000). Because GB is metabolically quite inert in plants, it remains in the plant cytosol and chloroplasts for several weeks (Preedy, 2015). When applied to the leaves of plants, glycine betaine is taken up by leaf tissues and roots (Park et al., 2006). The most of the glycine betaine that is taken up by the leaves is localized in the 
cytosol and only a small fraction of the cytosolic glycine betaine is translocated to chloroplasts (Park et al., 2006). Glycine betaine was translocated to actively growing and expanding parts of plants, the long-distance translocation of glycine betaine being mediated by the phloem (Mäkelä et al., 1996).

All forms of abiotic stress cause an oxidation reaction in plant cells. However, the presence of glycine betaine significantly reduced the production of $\mathrm{H}_{2} \mathrm{O}_{2}$ and efflux of $\mathrm{K}^{+}$ions dose-dependent on against abiotic stress (Cuin and Shabala, 2007; Chen and Murata, 2008). Glycine betaine mitigates the damaging effects of oxidative stress by activating or stabilizing reactive oxygen species (ROS)-scavenging enzymes and repressing the production of reactive oxygen species (Park et al., 2006). The accumulation of glycine betaine in chloroplasts and cytosol is effective in tolerating plants to abiotic stress (Wiśniewska et al., 2019). Glycine betaine counteracted the inhibitory effect of drought stress by the repair of photosystem II (PSII) (Ohnishi and Murata, 2006). Glycine betaine stabilizes and strengthens structures, increases enzymatic activity, and cell wall stability in the face of the damaging effects of stress is one of its activities. Therefore, the effect of methanol and glycine betaine as reducing agents of drought stress damage on sugar beet was investigated. KoukourikouPetridou and Koukounaras (2002) report methanol with glycine treatment increased root length and weight, and chlorophyll content. when used methanol alone, lead to achieving similar results as the control.

\section{Materials and Methods}

\section{Study context}

This experiment was performed as a combined split-factorial design based on randomized complete block design with 3 replications in two years (2018 and 2019) in, Isfahan, Iran (32\%43'29.8"N 51 $50^{\circ} 09.8^{\prime \prime} \mathrm{E}$ with 1543 meters above sea level).

\section{Sampling design and biological material}

The concentrations of methanol in 3 levels (control, 15 and 30\% v/v methanol) as the first treatment (A), and the concentrations of glycine betaine in 2 levels (control and 4 grams per liter (called $4 \mathrm{~g}$ )) as the second treatment (B) and 6 cultivars ('Sentinel', 'Drafter', 'Rivolta', 'Elanta', 'Rasta', and 'Qualita') were considered as the first factor. Soil texture was silty clay loamy with $\mathrm{pH}$ 7.5. At the harvest stage, random sampling of farms was done without margin effects.

\section{Qualitative analysis}

The plants were dried at $80^{\circ} \mathrm{C}$ to constant weight. The content of $\mathrm{Na}^{+}$and $\mathrm{K}^{+}$were determined using the flame spectrophotometer (FP640, Shanghai Precision \& Scientific Instrument) (Pi et al., 2016). The activity of nitrate reductase in leaves was investigated using Nicotinamide adenine dinucleotide (NADH) as a hydrogen donor by colorimetry (Zbieć et al., 2003). The activity of catalase enzyme measured catalase (CAT) activity was determined by measuring the decomposition rate of $\mathrm{H}_{2} \mathrm{O}_{2}$ in $60 \mathrm{~s}$ with spectrophotometer at 250 $\mathrm{nm}$ by Darwesh et al. (2018), CAT enzymatic activity was calculated using the system reported by Aebi (1984). For measurement of superoxide dismutase (SOD), $1 \mathrm{~mL}$ of reaction mixture was prepared in $50 \mathrm{mM}$ K-P buffer $(\mathrm{pH} 7.8)$ containing $2 \mu \mathrm{M}$ riboflavin, $75 \mu \mathrm{M}$ nitrotetrazolium blue (NBT), $100 \mu \mathrm{M}$ EDTA, $13 \mathrm{mM}$ DLmethionine and $60 \mu \mathrm{l}$ of enzyme extract and the absorbance was taken at $560 \mathrm{~nm}$ (Stewart and Bewley, 1980). Lipid peroxidation was determined by measuring the content of malondialdehyde (MDA) in leaves (Yang et al., 2015).

\section{Statistical procedures}

Analysis of variance was performed as a combined split-split factor based on randomized complete block design with 3 replications in two experimental years by SAS 9.4 software and Duncan's multiple range tests 
were used for means comparison. The results of soil at experimental station and the average annual temperature of 2018 and 2019 during the study shown in Table 1, and Table 2, respectively.

Table 1. The analysis of $\mathrm{pH}$, texture, organic carbon, nitrogen, phosphor and potassium of soil of study

\begin{tabular}{|c|c|c|c|c|c|c|}
\hline $\mathrm{pH}$ & Texture & $\begin{array}{c}\mathrm{EC} \\
\mathrm{dS} . \mathrm{m}-1\end{array}$ & $\begin{array}{c}\mathrm{O} . \mathrm{C} \\
(\%)\end{array}$ & $\begin{array}{c}\mathrm{N} \\
(\%)\end{array}$ & $\begin{array}{c}\mathrm{P}_{2} \mathrm{O}_{5} \\
(\mathrm{ppm})\end{array}$ & $\begin{array}{c}\mathrm{K}_{2} \mathrm{O} \\
(\mathrm{ppm})\end{array}$ \\
\hline 7.5 & SCL & 1.01 & 0.09 & 9 & 17.7 & 650 \\
\hline
\end{tabular}

Table 2. The average annual temperature during the years 2018 and 2019 of study

\begin{tabular}{|l|c|c|c|c|c|c|c|c|}
\hline & Oct-18 & Nov-18 & Dec-18 & Jan-19 & Feb-19 & Mar-19 & Apr-19 & May-19 \\
\hline High Temp & 33.8 & 23 & 17.2 & 17.2 & 22.6 & 23.6 & 29 & 36.2 \\
\hline Low Temp & 8 & -2.8 & -5.4 & -5.6 & -8.2 & -1.2 & 4.4 & 9.6 \\
\hline Aver Temp & 18.8 & 8.9 & 6.2 & 4.5 & 7.5 & 10.4 & 15.6 & 23.2 \\
\hline & Oct-19 & Nov-19 & Dec-19 & Jan-20 & Feb-20 & Mar-20 & Apr-20 & May-20 \\
\hline High Temp & 33.8 & 23 & 16.6 & 13 & 22.6 & 23.6 & 29 & 36.2 \\
\hline Low Temp & 8.6 & -2.8 & -3.4 & -5.6 & -8.2 & -1.2 & 6 & 9.6 \\
\hline Ave Temp & 19 & 7.9 & 5.9 & 3.4 & 8.3 & 11.2 & 16.2 & 23.7 \\
\hline
\end{tabular}

\section{Results}

\section{Root yield}

The effect of year on root yield was significant at the $1 \%$ probability (Table 3 ). The highest root yield was observed in year 2 and the lowest root yield was observed in year 1 (Table 4). Increasing the concentrations of glycine betaine by maintaining photosynthetic capacity, and the membrane structure improved plant performance (Ma et al., 2007; Cha-um et al., 2019). Similarly, Afshar et al. (2008) reported that glycine betaine significantly increased corn yield. The effect of methanol spraying on root yield was significant at the $1 \%$ probability level (Table 3). The highest root yield was observed in methanol treatment of $30 \% \mathrm{v} / \mathrm{v}$ and the lowest root yield was observed in non-methanol application treatment (Table 4). Dorokhov et al. (2018) has shown that methanol-treated plants can increase their net photosynthesis and improve performance. It was concluded that application of the highest level of methanol spraying, showed $170 \%$ increase in the amount of the amino acid glycine betaine under drought stress condition. Drought stress increases the proline and glycine betaine amino acids in the leaves and increased with the exogenous application of glycine betaine. Also, Iqbal, Ashraf (2008) reported that glycine betaine led to an increase in relative water content (RWC) of sunflower leaves under water stress. The effect of cultivar on root yield was significant at the $1 \%$ probability (Table 3 ). The highest root yield was observed in cultivar treatment 3 and the lowest root yield was observed in 'Rasta' (Table 4). The effect of foliar application and root yield was significant at the five percent probability (Table 3 ). The highest root yield was achieved in year 2 with methanol $15 \%$ and glycine betaine $4 \mathrm{~g}$, and the lowest root yield was observed in yearl along with the non-application of methanol and glycine betaine (Table 4). Kurepin et al. (2019) showed that glycine betaine foliar application treatments increased sugar beet root yield compared to the control treatment. The increase in growth and yield of plants was due to the use of anti-stress solutions due to their effectiveness as an inhibitor of light respiration (Zbieć et al., 2003; Stepanov et al., 2020). 
Table 3. Analysis of variance for yield, sugar, potassium, sodium, CAT, SOD, nitrate reductase, rubisco, MDA

\begin{tabular}{|c|c|c|c|c|c|c|c|c|c|c|}
\hline & & & & & & M.S & & & & \\
\hline S.O.V & $\mathrm{DF}$ & Yield & Sugar & Potassium & Sodium & CAT & SOD & Nitrate reductase & RUBISCO & MDA \\
\hline Year & 1 & $37897.79^{* *}$ & $2084425.09^{* *}$ & $64565.49^{* *}$ & $13422.84^{* *}$ & $23.89^{* *}$ & $196.86^{* *}$ & $37.45^{*}$ & $12046.8^{* *}$ & $18899.66^{* *}$ \\
\hline Rep (Year) & 4 & $274.9^{* *}$ & $39542.03^{*}$ & $114.95^{*}$ & $13.42^{*}$ & 0.11 & $0.93^{*}$ & 2.52 & $86.04^{*}$ & 64.91 \\
\hline $\mathrm{A}$ & 2 & $3815.72^{* *}$ & $552236.82^{* *}$ & $1205.32^{* *}$ & $126.16^{* *}$ & $2.11^{* *}$ & $19.15^{* *}$ & 7.27 & $1129.46^{* *}$ & $2039.46^{* *}$ \\
\hline Year*A & 2 & $378.39^{*}$ & $58666.62^{*}$ & $331.83^{* *}$ & $56.22^{* *}$ & $0.47^{* *}$ & $2.41^{* *}$ & 10.24 & $132.89^{*}$ & $459.56^{* *}$ \\
\hline Rep $^{*}$ Year $^{*} \mathrm{~A}$ & 8 & 66.48 & 5939 & 18.81 & 6.9 & 0.07 & 0.34 & 3.77 & 22.62 & 31.4 \\
\hline $\mathrm{B}$ & 1 & $5081.26^{* *}$ & $626817.64^{* *}$ & $1370.35^{* *}$ & $151.22^{* *}$ & $3.56^{* *}$ & $20.81^{* *}$ & 2.65 & $1612.32^{* *}$ & $1716.54^{* *}$ \\
\hline $\mathrm{A}^{*} \mathrm{~B}$ & 2 & $399.7^{*}$ & $46372.51^{*}$ & 88.26 & $16.64^{*}$ & $0.16^{*}$ & $1.66^{*}$ & 0.73 & $112.75^{*}$ & $127.43^{*}$ \\
\hline Year*A*B & 3 & $319.27^{*}$ & $33186.76^{*}$ & $223.84^{* *}$ & $36.66^{* *}$ & $0.27^{*}$ & 0.72 & $14.45^{*}$ & $111.25^{*}$ & 21 \\
\hline Rep $^{*}$ Year* $^{*}{ }^{*} B$ & 12 & 69.38 & 9487.34 & 43.34 & 5.2 & 0.07 & 0.38 & 4.71 & 27.18 & 33.77 \\
\hline $\mathrm{C}$ & 5 & $1528.86^{* *}$ & $204233.34^{* *}$ & $572.88^{* *}$ & $63.73^{* *}$ & $0.79^{* *}$ & $6.93^{* *}$ & $13.12^{*}$ & $464.11^{* *}$ & $635.3^{* *}$ \\
\hline Year $^{*} \mathrm{C}$ & 5 & 111.14 & 12957.42 & $111.7^{*}$ & $18.98^{* *}$ & $0.13^{*}$ & 0.55 & 4.78 & 35.97 & $74.55^{*}$ \\
\hline $\mathrm{A}^{*} \mathrm{C}$ & 10 & $168.4^{*}$ & $25040.29^{*}$ & $71.68^{*}$ & $10.92^{*}$ & 0.09 & $0.87^{*}$ & 1.74 & $53.18^{*}$ & $93.07^{* *}$ \\
\hline $\mathrm{B}^{*} \mathrm{C}$ & 5 & 102.07 & 15196.35 & 50.03 & 4.85 & 0.05 & 0.58 & 2.53 & 30.27 & 56.43 \\
\hline $\mathrm{A}^{*} \mathrm{~B}^{*} \mathrm{C}$ & 10 & 86.32 & 10650.56 & 43.61 & 4.1 & 0.04 & 0.44 & 1.63 & 24.53 & 39.64 \\
\hline Year ${ }^{*} \mathrm{~A}^{*} \mathrm{~B}^{*} \mathrm{C}$ & 25 & $134.32^{*}$ & $18881.84^{*}$ & $56.33^{*}$ & $7.31^{*}$ & $0.1^{*}$ & $0.7^{*}$ & 4.39 & $42.48^{*}$ & $64.95^{*}$ \\
\hline Error & 120 & 67.49 & 10101.9 & 29.45 & 3.56 & 0.05 & 0.32 & 4.04 & 21.28 & 28.19 \\
\hline
\end{tabular}

${ }^{*}$ Significant at 0.05 significance, ${ }^{* *}$ significant at 0.01 . A: Methanol concentration; B: Glycine betaine concentration; C: Cultivar

Table 4. Mean comparison of year, methanol and glycine betaine foliar application on yield, sugar, potassium, sodium, CAT, SOD, nitrate reductase, rubisco, MDA

\begin{tabular}{|c|c|c|c|c|c|c|c|c|c|}
\hline \multirow{2}{*}{ Year } & Yield & Sugar & Potassium & Sodium & CAT & SOD & Nitrate reductase & RUBISCO & MDA \\
\hline & $\left(\right.$ t.ha $\left.{ }^{-1}\right)$ & $\left(\mathrm{mg} . \mathrm{g}^{-1} \mathrm{DW}\right)$ & $\left(\mathrm{mg} \cdot \mathrm{g}^{-1} \mathrm{DW}\right)$ & $\left(\mathrm{mg} \cdot \mathrm{g}^{-1} \mathrm{DW}\right)$ & $\left(\right.$ u. $\left.\mathrm{mg}^{-1} \mathrm{pr}^{-1}\right)$ & $\left(\right.$ u.mg $\left.{ }^{-1} \mathrm{pr}^{-1}\right)$ & $\left(\mu\right.$ mol. $\left.\mathrm{NO}_{2} \cdot \mathrm{g}^{-1} \mathrm{~h}^{-1}\right)$ & $\left(\mu \mathrm{mol} \cdot \mathrm{m}^{-2} \mathrm{~s}^{-1}\right)$ & $\left(\mathrm{nm} \cdot \mathrm{mg}^{-1} \mathrm{pr}^{-1}\right)$ \\
\hline Year 1 & $47.01 \mathrm{~b}$ & $595.27 \mathrm{~b}$ & $20.94 \mathrm{~b}$ & $5.23 \mathrm{~b}$ & $1.58 \mathrm{~b}$ & $5.65 b$ & $9.11 \mathrm{~b}$ & $26.09 \mathrm{~b}$ & $65.29 \mathrm{~b}$ \\
\hline Year 2 & $73.51 \mathrm{a}$ & $791.74 a$ & $55.52 \mathrm{a}$ & $21 \mathrm{a}$ & $2.25 \mathrm{a}$ & $7.56 \mathrm{a}$ & $9.95 \mathrm{a}$ & $41.02 \mathrm{a}$ & $84 a$ \\
\hline \multicolumn{10}{|c|}{ Methanol concentration (A) } \\
\hline $0($ Met 0$)$ & $51.85 \mathrm{~b}$ & $592.64 \mathrm{~b}$ & $33.71 \mathrm{c}$ & $11.74 \mathrm{c}$ & $1.72 \mathrm{~b}$ & $6.01 \mathrm{~b}$ & $9.26 a$ & $28.98 b$ & $80.78 \mathrm{a}$ \\
\hline 15 (Met 15) & $64.46 a$ & $737.61 \mathrm{a}$ & $41.69 a$ & $14.39 a$ & $2.02 \mathrm{a}$ & $6.89 \mathrm{a}$ & $9.46 a$ & $35.88 \mathrm{a}$ & $71.77 \mathrm{~b}$ \\
\hline 30 (Met 30) & $64.47 \mathrm{a}$ & $750.26 a$ & $39.29 b$ & $13.21 \mathrm{~b}$ & $2.01 \mathrm{a}$ & $6.91 \mathrm{a}$ & $9.88 \mathrm{a}$ & $35.8 \mathrm{a}$ & $71.37 \mathrm{~b}$ \\
\hline \multicolumn{10}{|c|}{ Glycine betaine (B) } \\
\hline 0 (Gly 0$)$ & $55.41 \mathrm{~b}$ & $639.63 \mathrm{~b}$ & $35.71 \mathrm{~b}$ & $12.28 \mathrm{~b}$ & $1.79 \mathrm{~b}$ & $6.29 \mathrm{~b}$ & $9.42 \mathrm{a}$ & $30.82 \mathrm{~b}$ & $71.82 \mathrm{~b}$ \\
\hline 4 (Gly 4) & $65.11 \mathrm{a}$ & $747.37 \mathrm{a}$ & $40.75 a$ & $13.95 \mathrm{a}$ & $2.04 \mathrm{a}$ & $6.91 \mathrm{a}$ & $9.64 a$ & $36.29 a$ & $77.46 a$ \\
\hline \multicolumn{10}{|c|}{ Cultivar (C) } \\
\hline Sentinel & $60.97 \mathrm{c}$ & $697.97 \mathrm{c}$ & $38.49 \mathrm{~b}$ & $13.29 \mathrm{~b}$ & $1.91 \mathrm{~b}$ & $6.64 \mathrm{~b}$ & $9.65 \mathrm{a}$ & $33.83 \mathrm{~b}$ & $74.2 \mathrm{~b}$ \\
\hline Drafter & $58.02 c$ & $662.74 \mathrm{c}$ & $37.17 \mathrm{~b}$ & $12.76 \mathrm{~b}$ & $1.89 \mathrm{~b}$ & $6.44 \mathrm{~b}$ & $9.39 a$ & $32.38 \mathrm{~b}$ & $76.71 \mathrm{~b}$ \\
\hline Rivolta & $68.97 \mathrm{a}$ & $795.09 a$ & $43.33 a$ & $14.72 \mathrm{a}$ & $2.1 \mathrm{a}$ & $7.17 \mathrm{a}$ & $9.78 \mathrm{a}$ & $38.35 \mathrm{a}$ & $69.51 \mathrm{c}$ \\
\hline Elanta & $58.47 \mathrm{c}$ & $683.86 \mathrm{c}$ & $37.34 \mathrm{~b}$ & $12.79 \mathrm{~b}$ & $1.85 \mathrm{~b}$ & $6.5 \mathrm{~b}$ & $10.26 \mathrm{a}$ & $32.42 \mathrm{~b}$ & $74.75 \mathrm{~b}$ \\
\hline Rasta & $50.04 \mathrm{~d}$ & $574.56 \mathrm{~d}$ & $31.74 \mathrm{c}$ & $10.92 \mathrm{c}$ & $1.69 \mathrm{c}$ & $5.91 \mathrm{c}$ & $8.44 \mathrm{~b}$ & $27.99 \mathrm{c}$ & $81.42 \mathrm{a}$ \\
\hline Qualita & $65.09 \mathrm{~b}$ & $746.79 \mathrm{~b}$ & $41.29 \mathrm{a}$ & $14.2 \mathrm{a}$ & $2.05 a$ & $6.95 a$ & $9.67 \mathrm{a}$ & $36.35 a$ & $71.27 \mathrm{c}$ \\
\hline
\end{tabular}

Common letters within each column do not differ significantly

\section{Potassium}

The effect of location on potassium levels was significant at the $1 \%$ probability (Table 3 ). The highest amount of potassium was observed in year 2 treatment and the lowest amount of potassium was obtained in year 1 treatment (Table 4). Studies by Amin et al. (2013) showed that drought adversely affects the quality of sugar beet by increasing impurities such as alpha-amino, nitrogen, sodium, potassium, and reducing the amount of sugar that can be extracted. The effect of methanol foliar application of potassium levels was significant at the $1 \%$ probability level (Table 3). The highest amount of potassium was observed in the treatment of $15 \% \mathrm{v} / \mathrm{v}$ methanol and the lowest amount of potassium was observed in the treatment of non-application of methanol (Table 4). Sucrose has the ability to replace $\mathrm{K}^{+}$and $\mathrm{Na}^{+}$in vacuoles (Cha-um et al., 2019) and during growth, the concentrations of sucrose and $\mathrm{K}^{+}$are inversely related (Hoffmann et al., 2018). Under condition of drought stress, the stomata are closed and the stomatal conductance in the leaves and the penetration of $\mathrm{CO}_{2}$ and the production of carbohydrates is limited (Hsiao, 2000). However, the results of the experiments of Nadali et al. (2010) on sugar beet indicated that sodium, potassium, and nitrogen were not affected by methanol levels, which was inconsistent with the results of this experiment. The effect of glycine betaine foliar application concentration on potassium levels at the $1 \%$ probability level was significant (Table 3 ). The highest amount of potassium in glycine betaine treatment was $4 \mathrm{~g}$, and the lowest amount of potassium was observed in the control 
treatment (Table 4). Mäck and Hoffmann (2006) showed that glycine betaine, along with potassium, play a major role in the osmotic activity of sugar beet. The effect of cultivar on potassium levels was significant at the $1 \%$ probability level (Table 3 ). The highest amount of potassium was observed in the treatment of 'Rivolta' and the lowest amount of potassium was observed in the treatment of 'Rasta' (Table 4). Hadir et al. (2021) reported that a significant difference between the six cultivars evaluated in terms of root potassium. The effect of foliar application and potassium content was significant at the $1 \%$ probability level (Table 3 ). The highest potassium was observed in the year 2 treatment with 15\% methanol and $4 \mathrm{~g}$ of glycine betaine and the lowest potassium was observed in the year 1 treatment along with non-application of methanol and glycine betaine (Table 5).

Table 5. Mean comparison of interaction between year, methanol and glycine betaine foliar application on yield, sugar, potassium, sodium, CAT, SOD, nitrate reductase, rubisco

\begin{tabular}{|c|c|c|c|c|c|c|c|c|c|}
\hline \multirow[t]{2}{*}{ Treatment } & Yield & Sugar & Potassium & Sodium & CAT & SOD & $\begin{array}{c}\text { Nitrate } \\
\text { reductase }\end{array}$ & RUBISCO & MDA \\
\hline & $\left(\right.$ t.ha $\left.^{-1}\right)$ & $\left(\mathrm{mg}^{-1}{ }^{-1} \mathrm{DW}\right)$ & $\left(\mathrm{mg} \cdot \mathrm{g}^{-1} \mathrm{DW}\right)$ & $\left(\mathrm{mg}^{-1}{ }^{-1} \mathrm{DW}\right)$ & $\left(\right.$ u.mg $\left.{ }^{-1} \mathrm{pr}^{-1}\right)$ & $\left(\right.$ u. $\left.\mathrm{mg}^{-1} \mathrm{pr}^{-1}\right)$ & $\left(\mu \mathrm{mol} . \mathrm{NO}_{2} \cdot \mathrm{g}^{-1} \mathrm{~h}^{-1}\right)$ & $\left(\mu \mathrm{mol} . \mathrm{m}^{-2} \mathrm{~s}^{-1}\right)$ & $\left(\mathrm{nm} \cdot \mathrm{mg}^{-1} \mathrm{pr}^{-1}\right)$ \\
\hline Year1 Met0 Gly0 & $36.1 \mathrm{~g}$ & $459.38 \mathrm{f}$ & $16.19 \mathrm{~g}$ & $4.1 \mathrm{~g}$ & $1.33 \mathrm{~g}$ & $4.81 \mathrm{f}$ & $8 \mathrm{c}$ & $20.15 \mathrm{~g}$ & $93.73 a$ \\
\hline Year1 Met0 Gly4 & $38.67 \mathrm{~g}$ & $489.97 \mathrm{f}$ & $17.69 \mathrm{~g}$ & $4.39 \mathrm{fg}$ & $1.4 \mathrm{~g}$ & $5.02 \mathrm{f}$ & $8.94 \mathrm{bc}$ & $21.39 \mathrm{~g}$ & $91.47 \mathrm{a}$ \\
\hline Year1 Met15 Gly0 & $47.59 \mathrm{f}$ & $598.18 \mathrm{e}$ & $21.33 \mathrm{f}$ & $5.27 \mathrm{efg}$ & $1.56 \mathrm{f}$ & $5.7 \mathrm{e}$ & $9.25 \mathrm{abc}$ & $26.33 f$ & $83.21 \mathrm{~b}$ \\
\hline Year1 Met15 Gly4 & $52 \mathrm{f}$ & $654.58 \mathrm{de}$ & $22.75 \mathrm{ef}$ & $5.71 \mathrm{e}$ & $1.67 \mathrm{f}$ & $6.04 \mathrm{e}$ & $8.81 \mathrm{bc}$ & $28.85 \mathrm{f}$ & $79.29 \mathrm{c}$ \\
\hline Year1 Met30 Gly0 & $48.83 \mathrm{f}$ & $626.08 \mathrm{de}$ & $21.82 \mathrm{f}$ & $5.45 \mathrm{ef}$ & $1.65 \mathrm{f}$ & $5.79 \mathrm{e}$ & 9.31abc & $27.19 \mathrm{f}$ & $82 \mathrm{bc}$ \\
\hline Year1 Met30 Gly4 & $58.9 \mathrm{de}$ & $743.42 b$ & $25.84 \mathrm{e}$ & $6.45 \mathrm{e}$ & $1.89 \mathrm{e}$ & $6.54 \mathrm{~d}$ & $10.38 \mathrm{a}$ & $32.6 \mathrm{e}$ & $74.28 \mathrm{~d}$ \\
\hline Year2 Met0 Gly0 & 62.68de & $673.31 \mathrm{~cd}$ & $48.35 \mathrm{~d}$ & $18.34 \mathrm{~d}$ & $1.95 \mathrm{e}$ & $6.88 \mathrm{~cd}$ & $10.33 a$ & $34.96 \mathrm{de}$ & $70.89 \mathrm{de}$ \\
\hline Year2 Met0 Gly4 & $69.97 \mathrm{bc}$ & $747.9 \mathrm{~b}$ & $52.6 \mathrm{c}$ & $20.14 \mathrm{bc}$ & $2.19 \mathrm{c}$ & $7.32 \mathrm{~b}$ & $9.75 \mathrm{ab}$ & $39.43 \mathrm{bc}$ & $67.05 f$ \\
\hline Year2 Met15 Gly0 & $71.51 \mathrm{~b}$ & $758.91 \mathrm{~b}$ & $54.74 \mathrm{bc}$ & $20.72 b c$ & $2.19 \mathrm{~cd}$ & $7.47 \mathrm{~b}$ & $9.23 \mathrm{abc}$ & $39.74 b$ & $65.82 \mathrm{f}$ \\
\hline Year2 Met15 Gly4 & $86.74 a$ & $938.78 \mathrm{a}$ & $67.92 \mathrm{a}$ & $25.84 \mathrm{a}$ & $2.64 \mathrm{a}$ & $8.36 \mathrm{a}$ & $10.55 \mathrm{a}$ & $48.61 \mathrm{a}$ & $58.76 \mathrm{~g}$ \\
\hline Year2 Met30 Gly0 & $65.75 \mathrm{~cd}$ & $721.93 b c$ & $51.81 \mathrm{~cd}$ & $19.77 \mathrm{c}$ & $2.04 \mathrm{de}$ & $7.11 b c$ & $10.4 \mathrm{a}$ & $36.56 \mathrm{~cd}$ & $69.11 \mathrm{ef}$ \\
\hline Year2 Met30 Gly4 & $84.38 \mathrm{a}$ & $909.59 a$ & $57.66 \mathrm{~b}$ & $21.16 b$ & $2.47 \mathrm{~b}$ & $8.21 \mathrm{a}$ & $9.42 \mathrm{ab}$ & $46.83 a$ & $60.1 \mathrm{~g}$ \\
\hline
\end{tabular}

Common letters within each column do not differ significantly

\section{Sodium}

The effect of location on sodium levels was significant at the $1 \%$ probability level (Table 3 ). The highest amount of sodium was observed in year 2 treatment and the lowest amount of sodium was observed in year 1 treatment (Table 4). The effect of methanol foliar application of sodium content was significant at the $1 \%$ probability level (Table 3). The highest amount of sodium was observed in the treatment of $15 \% \mathrm{v} / \mathrm{v}$ methanol and the lowest amount of sodium was observed in the treatment of non-consumption of methanol (Table 4). The effect of glycine betaine foliar application concentration on sodium content was significant at the $1 \%$ probability level (Table 3). The highest amount of sodium in glycine betaine treatment was $4 \mathrm{~g}$ and the lowest amount of sodium was observed in the control treatment (Table 4). Glycine betaine by regulating the ratio of sodium: Potassium is involved in the plant's tolerance to salt. Reza et al. (2006) noted that sodium accumulation was significantly increased in aerial parts and wheat roots due to salinity stress, and the use of glycine betaine increased sodium accumulation with increasing potassium accumulation. The effect of cultivar on the sodium level at the probability level was one percent significant (Table 3). The highest amount of sodium was observed in the treatment of 'Rivolta' and the lowest amount of sodium was observed in the treatment of 'Rasta' (Table 4). The effect of foliar application and the amount of sodium on the probability level was one percent significant (Table 3).

\section{Catalase activity}

The effect of location on catalase enzyme activity (CAT) was significant at the $1 \%$ probability level (Table 3). The highest activity of catalase enzyme was observed in year 2 treatment and the lowest activity of catalase enzyme was observed in year 1 treatment (Table 4). Branch (2009) reported that plants under drought stress have a significant increase in SOD and CAT activity in canola leaves. The different activities of antioxidant enzymes in different genotypes can be related to different genetic behaviours to tolerate drought stress conditions. The effect of methanol spraying on catalase enzyme activity was significant at the $1 \%$ probability level (Table 3). The highest activity of catalase enzyme in the treatment of methanol was observed 
in $15 \% \mathrm{v} / \mathrm{v}$ and the lowest activity of catalase enzyme in the treatment of non-methanol application was observed (Table 4). It has been reported an increase of nearly 10 times in the production of catalase enzyme was observed on plants under drought stress conditions. The enzyme catalase protects cells against hydrogen peroxide and plays an important role in resistance to oxidative stress. Methanol through the absorption of iron, which is a prosthetic group of hemoproteins such as catalase, peroxidase, and superoxide dismutase, could be involved in the destruction of active oxygen species in plants (Blokhina et al., 2003; Keles and Öncel, 2004).

The effect of glycine betaine foliar application concentration on catalase activity was significant at the $1 \%$ probability level (Table 3 ). The highest catalase activity was observed in $4 \mathrm{~g}$ glycine betaine treatment and the lowest catalase activity was observed in the control treatment (Table 4). Cruz et al. (2013) study mentioned that the CAT activities in well-watered plants were not influenced by the glycine betaine exogenous application, but in water-stressed plants, the CAT activity significantly increased. The effect of cultivar on catalase activity was significant at the $1 \%$ probability level (Table 3 ). The highest catalase activity was observed in the treatment of 'Rivolta' and the lowest catalase activity was observed in the treatment of 'Rasta' (Table 4). Prajapat et al. (2018) stated the activity of CAT increased in drought-tolerant cultivars of maize. Besides, Fu and Huang (2001) reported that the ability for adaptation to drought stress depended on the maintenance of or increases in the capability to detoxify superoxide radical by antioxidant enzymes. The effect of foliar application and catalase activity at the level of probability was significant at five percent (Table 3). The highest activity of catalase enzyme was observed in the treatment of year 2 with methanol 15 and glycine betaine $4 \mathrm{~g}$, and the lowest activity of catalase enzyme was observed in the treatment of year 1 with non-consumption of methanol and glycine betaine (Table 5). Plants treated with glycine betaine showed an increase in glycine betaine-treated plants exhibited increased levels of photosystem II (PSII) activity compared with control plants. Glycine betaine-treated plants had significantly greater catalase activity. This result suggests that glycine betaine may enhance the induction of antioxidant mechanisms under abiotic stress conditions.

\section{Superoxide dismutase activity}

The effect of location on the level of superoxide dismutase activity (SOD) was significant at the $1 \%$ probability level (Table 3). The highest superoxide dismutase activity was observed in year 2 treatment and the lowest superoxide dismutase activity dismutase was observed in year 1 treatment (Table 4). It has been reported that in the absence of stress, the application of methanol did not have a significant effect on the SOD in the leaves. However, under stress conditions, methanol levels significantly reduced the activity of this enzyme compared to the non-methanol application under stress conditions. The effect of methanol spraying on the level of SOD was significant at the $1 \%$ probability level (Table 3). The highest SOD in methanol treatment was observed to be $30 \% \mathrm{v} / \mathrm{v}$, and the lowest SOD was observed in the treatment of the non-methanol application (Table 4). Application of methanol in different climatic conditions due to the fact that it provides more carbon dioxide to the leaves of the plant, the plant is less exposed to adverse environmental conditions and as a result, the production of oxygen free radicals is reduced. Due to the reduction in free radicals, the plant needs less antioxidant enzymes, However, Romandini et al. (1994) believed that the presence of methanol did not affect the enzymatic levels, while the absence of glucose gave higher SOD levels. It has been reported that the highest amount of superoxide dismutase enzyme was observed in soybean with 6 units per $\mathrm{mg}$ of protein under conditions of extreme moisture stress without methanol spraying and increasing the intensity of moisture stress increased the production of this enzyme. The effect of glycine betaine foliar application concentration on the superoxide dismutase activity was significant at the $1 \%$ probability level (Table 3 ). The highest superoxide dismutase activity was observed in $4 \mathrm{~g}$ glycine betaine treatment and the lowest superoxide dismutase activity was observed in the control treatment (Table 4). The effect of glycine betaine foliar application concentration on the superoxide dismutase activity at a probability level of one percent was significant (Table 3). The highest superoxide dismutase activity in glycine betaine treatment was $4 \mathrm{~g}$, and the lowest superoxide dismutase activity was observed in the control treatment (Table 4). The effect of cultivar on the superoxide dismutase activity was significant at the $1 \%$ probability level (Table 3 ). The highest and lowest 
superoxide dismutase activity was observed in the treatment of 'Rivolta' and treatment of 'Rasta', respectively (Table 4). The reason for the difference in the response of cultivars seems to be related to their genetic differences and the process of their different growth. Superoxide dismutase is an antioxidant enzyme that catalyzes active superoxide anions and converts them to oxygen and low-activity types of hydrogen peroxide (Kumar et al., 2020). According to the results, cultivars that had better yield had higher superoxide dismutase activity under stress conditions. The effect of the year and foliar application and cultivar on the superoxide dismutase activity was not significant (Table 3 ).

\section{Nitrate reductase}

The effect of location on the nitrate reductase activity was significant at the five percent probability level (Table 3). The highest activity of the reductase nitrate enzyme was observed in year 2 treatment and the lowest activity of the reductase nitrate enzyme was observed in year 1 treatment (Table 4). The effect of methanol spraying on nitrate reductase activity was not significant (Table 3). According to previous study (Zbieć et al., 2003), increasing the amount of nitrate reductase during methanol application showed a significant difference compared to the control, also methanol increased CGR and nitrate reductase activity on rapeseed. The effect of glycine betaine foliar application and also the effect of cultivar on the nitrate reductase activity was not significant (Table 3). The effect of foliar application and cultivar on the nitrate reductase activity was significant at the $5 \%$ probability level (Table 3 ). The highest nitrate reductase activity was observed in year 2 treatment with methanol $15 \%$ and glycine betaine $4 \mathrm{~g}$ and the lowest nitrate reductase activity was observed in year 1 treatment along with the non-application of methanol and glycine betaine (Table 3 ).

\section{Rubisco activity}

The effect of location on rubisco activity was significant at the $1 \%$ probability level (Table 3 ). The highest rubisco activity in Year 2 treatment and the lowest rubisco activity in year 1 treatment was achieved (Table 4). In the year 1 region, due to higher temperatures and unfavourable environmental conditions the sugar beet plant, which is a C3 plant, had more light respiration (Table 3). With increasing light respiratory, the rubisco showed a lower level of activity. Cruz et al. (2013) showed that dehydration significantly reduced the stomatal conductivity and the ratio of $\mathrm{CO}_{2}$ concentration. In stress-tolerant plants, the rate of net assimilation rate decreased with the absence of $\mathrm{CO}_{2}$, which reduced the activity of carboxylase, rubisco, and stimulates plant respiration. The effect of methanol spraying on rubisco activity was significant at the $1 \%$ probability level (Table 3). The highest rubisco activity in methanol treatment was $15 \% \mathrm{v} / \mathrm{v}$ and the lowest rubisco activity was observed in the methanol non-application treatment (Table 4). Crafts-Brandner and Law (2000) stated that rubisco activity and photosynthesis declined under thermal stress conditions. They reported that increased in $\mathrm{CO}_{2}$ reduced rubisco activity on the leaves. Therefore, by increasing the $\mathrm{CO}_{2}$ concentration during methanol application, it can be shown that methanol could increase rubisco activity. The effect of glycine betaine foliar application on rubisco activity was significant at the $1 \%$ probability level (Table 3 ). The highest rubisco activity was observed in glycine betaine $4 \mathrm{~g}$ treatment, and the lowest rubisco activity was observed in the control treatment (Table 4). glycine betaine application protected chloroplast ultrastructure and prevented the decrease of chlorophyll and rubisco activity under salt- and drought-stress conditions (Mäkelä et al., 2000). The effect of cultivar on rubisco activity was significant at the $1 \%$ probability level (Table 3). The highest rubisco activity was observed in 'Rivolta' and the lowest rubisco activity was observed in 'Rasta' (Table 4). Studies have shown that there is more inhibition of the rubisco activity in the heat-sensitive cultivar than in the tolerant cultivars (Bose and Ghosh, 1995). The effect of the Year and foliar application and cultivar on rubisco activity was significant at the probability level of five percent (Table 3). The highest rate of rubisco activity was observed in year 2 treatment with $15 \mathrm{mg}$ of methanol and $4 \mathrm{~g}$ of glycine betaine, and the lowest level of rubisco activity in year 1 treatment was observed with non-methanol and glycine betaine application (Table 5). 


\section{Malondialdehyde concentration}

The effect of location on malondialdehyde concentration (MDA) was significant at the $1 \%$ probability level (Table 3). The highest malondialdehyde concentration was observed in year 2 treatment and the lowest malondialdehyde concentration was observed in year 1 treatment (Table 4). Malondialdehyde is considered a good indicator of membrane lipid peroxidation (Grotto et al., 2009). Drought stress increases with the content of oxygen free radicals, which increases the content of malondialdehyde to product the membrane peroxidation. An examination of the MDA content under a hydroponic cultivation system showed that the MDA malondialdehyde concentration in the roots of the two genotypes increased due to increased salinity (Chen et al., 2011). The effect of methanol foliar application on malondialdehyde concentration was significant at the $1 \%$ probability level (Table 3 ). The highest and lowest malondialdehyde concentration was observed in methanol non-application treatment and methanol treatment $30 \% \mathrm{v} / \mathrm{v}$ (Table 4 ). It has been stated that the highest malondialdehyde concentration was observed in conditions of non-methanol application and its value decreases significantly with increasing percentage of methanol. The effect of glycine betaine foliar application on malondialdehyde concentration was significant at the $1 \%$ probability level (Table 3 ). The highest malondialdehyde concentration in glycine betaine treatment was observed at $4 \mathrm{~g}$, and the lowest malondialdehyde concentration was observed in the control treatment (Table 4). It has been reported that, glycine betaine foliar application in sorghum and canola caused the path of amino acid synthesis changed to proline production, so the amount of proline increased with glycine betaine foliar application in the plant (Kadkhodaei et al., 2016). The effect of cultivar on malondialdehyde concentration was significant at the 1\% probability level (Table 3). The highest malondialdehyde concentration was observed in the treatment of Rasta and the lowest malondialdehyde concentration was observed in the treatment of 'Rivolta' (Table 4). The effect of foliar application and cultivar on malondialdehyde concentration was not significant (Table 3). The shoot GB concentrations were closely correlated with leaf water potential. Salt-induced GB accumulation in the shoot could also contribute to cytoplasmic osmoregulation in beet leaves, and so play an important role in their salt tolerance. However, the contribution of GB to achieve osmotic balance in roots varied among genotypes. The response of sugar beet, and differed with regard to the accumulation of solutes in the storage root after drought stress (Hoffmann, 2014).

\section{Conclusions}

The effect of year was significant on yield, sugar, potassium, sodium, CAT, SOD, nitrate reductase, RUBISCO, and MDA. The effect of methanol spraying on root yield was significant the highest yield was observed in methanol treatment of $30 \% \mathrm{v} / \mathrm{v}$ and the lowest root yield was observed in non-methanol application treatment. The maximum amount of potassium was observed in the treatment of $15 \% \mathrm{v} / \mathrm{v}$ methanol, and the lowest amount of potassium was related to the treatment of non-application of methanol. The highest amount of potassium was observed in the treatment of 'Rivolta' and the lowest amount of potassium was observed in the treatment of 'Rasta'. Application of $15 \%$ methanol and $4 \mathrm{~g}$ of glycine betaine had obtained the highest potassium content and the minimum one was observed in the year 1 treatment along with non-application of methanol and glycine betaine. The highest amount of sodium was observed in the treatment of 'Rivolta', and the lowest amount of sodium was related to treatment of 'Rasta'. The impact of methanol spraying and glycine betaine foliar application on catalase enzyme activity was meaningful at the $1 \%$ probability level. The highest activity of catalase enzyme was observed in the treatment of year 2 with methanol 15 and glycine betaine $4 \mathrm{~g}$, and the lowest activity of catalase enzyme was observed in the treatment of year 1 with non-consumption of methanol and glycine betaine. The effect of the year and foliar application as well as cultivar on the superoxide dismutase was not meaningful. The maximum nitrate reductase activity was observed in year 2 treatment along with methanol $15 \%$ and glycine betaine $4 \mathrm{~g}$ and the lowest nitrate reductase activity was related to year 1 treatment along with the non-application of glycine betaine and methanol. The 
highest malondialdehyde concentration was related to the 'Rasta' and the lowest one was observed in the treatment of 'Rivolta'. The impact of foliar application and cultivar on malondialdehyde concentration was not significant. Based on the results, the application methanol 15\% v/v with glycine betaine $4 \mathrm{~g}$ per liter are recommended to improve the quality of the sugar beet under similar conditions of the present experiment.

\section{Authors' Contributions}

All authors read and approved the final manuscript.

\section{Acknowledgements}

This research received no specific grant from any funding agency in the public, commercial, or not-forprofit sectors.

\section{Conflict of Interests}

The authors declare that there are no conflicts of interest related to this article.

\section{References}

Achkor H, Díaz M, Fernández MR, Biosca JA, Parés X, Martínez MC (2003). Enhanced formaldehyde detoxification by overexpression of glutathione-dependent formaldehyde dehydrogenase from Arabidopsis. Plant Physiology 132:2248-2255. https://doi.org/10.1104/pp.103.022277

Aebi H (1984). Catalase in vitro. Methods in Enzymology 105:121-126. https://doi.org/10.1016/s0076$6879(84) 05016-3$

Albayrak S, Camas N (2007). Effects of temperature and light intensity on growth of fodder beet (Beta vulgaris L. var. crassa Mansf.). Bangladesh Journal of Botany 36:1-12. https://doi.org/10.3329/bjb.v36i1.1542

Amin GA, Badr EA, Afifi M (2013). Root yield and quality of sugar beet (Beta vulgaris L.) in response to biofertilizer and foliar application with micronutrients. World Applied Sciences Journal 27:1385-1389.

Ashraf M, Foolad MR (2007). Roles of glycine betaine and proline in improving plant abiotic stress resistance. Environmental and Experimental Botany 59:206-216. https://doi.org/10.1016/j.envexpbot.2005.12.006

Ashraf M, Nawaz K, Raza S (2008). Growth enhancement in two potential cereal crops, maize and wheat, by exogenous applicationation of glycinebetaine. In: Biosaline Agriculture and High Salinity Tolerance. Springer, pp 21-35. https://doi.org/10.1007/978-3-7643-8554-5_2

Behrouzyar EK, Yarnia M (2016). Effects of methanol foliar application on nutrient content and RWC of sugar beet under water deficit stress. Bangladesh Journal of Botany 45:1069-1074.

Blokhina O, Virolainen E, Fagerstedt KV (2003). Antioxidants, oxidative damage and oxygen deprivation stress: a review. Annals of Botany 91:179-194. https://doi.org/10.1093/aob/mcf118

Bose A, Ghosh B (1995). Effect of heat stress on ribulose 1, 5-bisphosphate carboxylase in rice. Phytochemistry 38:11151118.

Cha-um S, Rai V, Takabe T (2019). Proline, glycinebetaine, and trehalose uptake and inter-organ transport in plants under stress. In: Osmoprotectant-Mediated Abiotic Stress Tolerance in Plants. Springer, pp 201-223. https://doi.org/10.1007/978-3-030-27423-8_9

Chen Q, Zhang M, Shen S (2011). Effect of salt on malondialdehyde and antioxidant enzymes in seedling roots of Jerusalem artichoke (Helianthus tuberosus L.). Acta Physiologiae Plantarum 33:273-278. https://doi.org/10.1007/s11738-010-0543-5 
Chen THH, Murata N (2008). Glycinebetaine: an effective protectant against abiotic stress in plants. Trends in Plant Science 13:499-505. https://doi.org/10.1016/j.tplants.2008.06.007

Crafts-Brandner S, Law R (2000). Effect of heat stress on the inhibition and recovery of the ribulose-1, 5-bisphosphate carboxylase/oxygenase activation state. Planta 212:67-74.

Cruz F, Castro GLS, Júnior DS, Festucci-Buselli RA, Pinheiro HA (2013). Exogenous glycine betaine modulates ascorbate peroxidase and catalase activities and prevent lipid peroxidation in mild water-stressed Carapa guianensis plants. Photosynthetica 51:102-108.

Cuin TA, Shabala S (2007). Compatible solutes reduce ROS-induced potassium efflux in Arabidopsis roots. Plant, Cell \& Environment 30:875-885.

Darwesh OM, Sultan YY, Seif MM, Marrez DA (2018). Bio-evaluation of crustacean and fungal nano-chitosan for applying as food ingredient. Toxicology Reports 5:348-356. https://doi.org/10.1016/j.toxrep.2018.03.002

Demmers-Derks H, Mitchell RAC, Mitchell VJ, Driscoll SP, Gibbard C, Lawlor DW (1996). Sugar beet under climatic change: photosynthesis and production. Aspects of Applied Biology 45:163-170.

Dorokhov YL, Sheshukova EV, Komarova TV (2018). Methanol in plant life. Frontiers in Plant Science 9:1-16. https://doi.org/10.3389/fpls.2018.01623

Fall R, Benson AA (1996). Leaf methanol-the simplest natural product from plants. Trends in Plant Science 1:296-301. https://doi.org/10.1016/s1360-1385(96)88175-0

Felix JD, Roebuck JA, Mead RN, Willey JD, Avery Jr GB, Kieber RJ (2019). Methanol and ethanol concentrations in a Greenland ice core. Atmospheric Environment 217:116948. https://doi.org/10.1016/j.atmosenv.2019.116948

Fu J, Huang B (2001). Involvement of antioxidants and lipid peroxidation in the adaptation of two cool-season grasses to localized drought stress. Environmental and Experimental Botany 45:105-114.

Garrow TA (2015). Betaine-homocysteine S-methyltransferase. In: Betaine: Chemistry, Analysis, Function and Effects. The Royal Society of Chemistry, Chapter 7, pp 90-101. http://dx.doi.org/10.1039/9781782628446-00090

Grotto D, Maria LS, Valentini J, Paniz C, Schmitt G, Garcia SC, ... Farina M (2009). Importance of the lipid peroxidation biomarkers and methodological aspects for malondialdehyde quantification. Quimica Nova 32:169-174. https://doi.org/10.1590/s0100-40422009000100032

Hadir S, Gaiser T, Hüging H, Athmann M, Pfarr D, Kemper R, ... Seidel S (2021). Sugar beet shoot and root phenotypic plasticity to nitrogen, phosphorus, potassium and lime omission. Agriculture 11:1-1. https://doi.org/10.3390/agriculture11010021

Haslam R, Rust S, Pallett K, Cole D, Coleman J (2002). Cloning and characterisation of S-formylglutathione hydrolase from Arabidopsis thaliana: a pathway for formaldehyde detoxification. Plant Physiology Biochemistry 40:281288. https://doi.org/10.1016/s0981-9428(02)01378-5

Hasunuma T, Fukusaki E-i, Kobayashi A (2004). Expression of fungal pectin methylesterase in transgenic tobacco leads to alteration in cell wall metabolism and a dwarf phenotype. Journal of Biotechnology 111:241-251. https://doi.org/10.1016/j.jbiotec.2004.04.015

Hoffmann C (2014). Adaptive responses of Beta vulgaris L. and Cichorium intybus L. root and leaf forms to drought stress. Journal of Agronomy and Crop Science 200:108-118.

Hoffmann CM, Leijdekkers M, Ekelöf J, Vancutsem F (2018). Patterns for improved storability of sugar beet-importance of marc content and damage susceptibility of varieties in different environments. European Journal of Agronomy 101:30-37.

Hsiao TC (2000). Leaf and root growth in relation to water status. HortScience 35:1051-1057.

Iqbal N, Ashraf M, Ashraf M (2008). Glycine betaine, an osmolyte of interest to improve water stress tolerance in sunflower (Helianthus annuus L.): water relations and yield. South African Journal of Botany 74:274-281. https://doi.org/10.1016/j.sajb.2007.11.016

Joshi R, Wani SH, Singh B, Bohra A, Dar ZA, Lone AA, ... Singla-Pareek SL (2016). Transcription factors and plants response to drought stress: current understanding and future directions. Frontiers in Plant Science 7:1029. https://doi.org/10.3389/fpls.2016.01029

Kadkhodaei H, Sodaeizadeh H, Arany AM, Hakim Zadeh MA (2016). The role of glycine betaine in increasing drought resistance of Sorghum halopens under field condition. Environmental Stresses in Crop Sciences 9:139-147.

Keles Y, Öncel I (2004). Growth and solute composition in two wheat species experiencing combined influence of stress conditions. Russian Journal of Plant Physiology 51:203-209.

Khan SU, Khan A, Naveed S (2015). Effect of exogenously applied kinetin and glycine betaine on metabolic and yield attributes of rice (Oryza sativa L.) under drought stress. Emirates Journal of Food and Agriculture 75-81. 
Kordic S, Cummins I, Edwards R (2002). Cloning and characterization of an S-formylglutathione hydrolase from Arabidopsis thaliana. Archives of Biochemistry 399:232-238. https://doi.org/10.1006/abbi.2002.2772

Koukourikou-Petridou M, Koukounaras A (2002). The effect of methanol on the growth and chlorophyll content of tomato and pepper. International Society for Horticultural Science (ISHS), Leuven, Belgium. pp 271-274. https://doi.org/10.17660/ActaHortic.2002.579.45

Kumar RR, Dubey K, Goswami S, Hasija S, Pandey R, Singh PK, ... Praveen S (2020). Heterologous expression and characterization of novel manganese superoxide dismutase (Mn-SOD) - A potential biochemical marker for heat stress-tolerance in wheat (Triticum aestivum). International Journal of Biological Macromolecules 161:10291039. https://doi.org/10.1016/j.jibiomac.2020.06.026

Kurepin LV, Ivanov AG, Zaman M, Pharis RP, Allakhverdiev SI, Hurry V, Hüner NP (2015). Stress-related hormones and glycinebetaine interplay in protection of photosynthesis under abiotic stress conditions. Photosynthesis Research 126:221-235. https://doi.org/10.1007/s11120-015-0125-X

Ma XL, Wang YJ, Xie SL, Wang C, Wang W (2007). Glycinebetaine application ameliorates negative effects of drought stress in tobacco. Russian Journal of Plant Physiology 54:472-479. https://doi.org/10.1134/s1021443707040061

Mäck G, Hoffmann CM (2006). Organ-specific adaptation to low precipitation in solute concentration of sugar beet (Beta vulgaris L.). European Journal of Agronomy 25:270-279. https://doi.org/10.1016/j.eja.2006.06.004

Mäkelä P (2004). Agro-industrial uses of glycinebetaine. Sugar Tech 6:207-212. https://doi.org/10.1007/bf02942500

Mäkelä P, Kärkkäinen J, Somersalo S (2000). Effect of glycinebetaine on chloroplast ultrastructure, chlorophyll and protein content, and RuBPCO activities in tomato grown under drought or salinity. Biologia Plantarum 43:471475. https://doi.org/10.1023/a:1026712426180

Mäkelä P, Peltonen-Sainio P, Jokinen K et al. (1996). Uptake and translocation of foliar-applied glycinebetaine in crop plants. Plant Science 121:221-230. https://doi.org/10.1016/s0168-9452(96)04527-X

McGiffen ME, Manthey JA (1996). The role of methanol in promoting plant growth: A current evaluation. HortScience 31:1092-1096.

Nadali I, Paknejad F, Moradi F, Vazan S, Tookalo M, Jami Al-Ahmadi M, Pazoki A (2010). Effects of methanol on sugar beet (Beta vulgaris). Australian Journal of Crop Science 4:398-401.

Nawaz M, Wang Z (2020). Abscisic acid and glycine betaine mediated tolerance mechanisms under drought stress and recovery in Axonopus compressus: A new insight. Scientific Reports 10:6942. https://doi.org/10.1038/s41598020-63447-0

Nonomura A, Benson A (1992). The path of carbon in photosynthesis: improved crop yields with methanol. Proceedings of the National Academy of Sciences 89:9794-9798. https://doi.org/10.1073/pnas.89.20.9794

Ohnishi N, Murata N (2006). Glycinebetaine counteracts the inhibitory effects of salt stress on the degradation and synthesis of D1 protein during photoinhibition in Synechococcus sp. PCC 7942. Plant Physiology 141:758-765. https://doi.org/10.1104/pp.106.076976

Park E-J, Jeknic Z, Chen TH (2006). Exogenous application of glycinebetaine increases chilling tolerance in tomato plants. Plant and cell physiology 47:706-714.

Pi Z, Stevanato P, Sun F, Yang Y, Sun X, Zhao H, ... Yu L (2016). Proteomic changes induced by potassium deficiency and potassium substitution by sodium in sugar beet. Journal of Plant Research 129:527-538. https://doi.org/10.1007/s10265-016-0800-9

Prajapat P, Singh D, Tripathi S, Patel K, Abbas H, Patel A (2018). Effect of water stress on antioxidative enzymes and glycine betaine content in drought tolerant and drought susceptible cotton (Gossypium hirsutum L.) genotypes. Indian Journal of Biochemistry and Biophysics (IJBB) 3:198-204.

Rehman A, Khalil SK (2018). Effect of exogenous application of salicylic acid, potassium nitrate and methanol on canola growth and phenology under different moisture regimes. Sarhad Journal of Agriculture 34:781-789. https://doi.org/10.17582/journal.sja/2018/34.4.781.789

Reinhold L, Kaplan A (1984). Membrane transport of sugars and amino acids. Annual Review of Plant Physiology 35:4583. https://doi.org/10.1146/annurev.pp.35.060184.000401

Romandini P, Bonotto C, Bertoloni G, Beltramini M, Salvato B (1994). Superoxide dismutase, catalase and cell dimorphism in Candida albicans cells exposed to methanol and different temperatures. Comparative Biochemistry and Physiology Part C: Pharmacology, Toxicology and Endocrinology 108:53-57. https://doi.org/10.1016/1367$8280(94) 90089-2$ 
Saneienejad A, Tohidi M, Khaniani BH, Sadeghi M (2019). Effect of Foliar application of methanol on changes of antioxidant enzymes of Vigna unguiculata L. in water-deficit stress. Agricultural Science Digest 39:296-300. https://doi.org/10.18805/ag.d-169

Sheshukova EV, Komarova TV, Pozdyshev DV, Ershova NM, Shindyapina AV, Tashlitsky VN, ... Dorokhov YL (2017). The intergenic interplay between aldose 1-epimerase-like protein and pectin methylesterase in abiotic and biotic stress control. Frontiers in Plant Science 8:1-17. https://doi.org/10.3389/fpls.2017.01646

Stepanov SS, Zolotareva EK, Belyavskaya NA (2020). The role of catalase in assimilation of exogenous methanol by Chlamydomonas reinhardtii cells. Journal of Applied Phycology 1-10.

Stewart RR, Bewley JD (1980). Lipid peroxidation associated with accelerated aging of soybean axes. Plant Physiology 65:245-248. https://doi.org/10.1104/pp.65.2.245

Branch K (2009). Effect of super absorbent application on antioxidant enzyme activities in canola (Brassica napus L.) cultivars under water stress conditions. American Journal of Agricultural and Biological Sciences 4:215-223. https://doi.org10.3844/ajabssp.2009.215.223

Valizadeh-Kamran R, Vojodi Mehrabani L, Pessarakli M (2019). Effects of foliar application of methanol on some physiological characteristics of Lavandula stoechas $\mathrm{L}$. under $\mathrm{NaCl}$ salinity conditions. Journal of Plant Nutrition 42:261-268. https://doi.org/10.1080/01904167.2018.1554677

Wiśniewska A, Andryka-Dudek P, Czerwiński M, Choulj D (2019). Fodder beet is a reservoir of drought tolerance alleles for sugar beet breeding. Plant Physiology and Biochemistry 145:120-131. https://doi.org/10.1016/j.plaphy.2019.10.031

Yang C, Zhou Y, Fan J, Fu Y, Shen L, Yao Y, ... Guo J (2015). SpBADH of the halophyte Sesuvium portulacastrum strongly confers drought tolerance through ROS scavenging in transgenic Arabidopsis. Plant Physiology Biochemistry 96:377-387. https://doi.org/10.1016/j.plaphy.2015.08.010

Zbieć I, Karczmarczyk S, Podsiadło C (2003). Response of some cultivated plants to methanol as compared to supplemental irrigation. Electronic Journal of Polish Agricultural Universities 6:1-7.
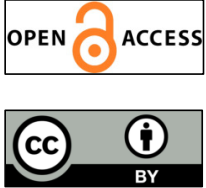

The journal offers free, immediate, and unrestricted access to peer-reviewed research and scholarly work. Users are allowed to read, download, copy, distribute, print, search, or link to the full texts of the articles, or use them for any other lawful purpose, without asking prior permission from the publisher or the author.

License - Articles published in Notulae Scientia Biologicae are Open-Access, distributed under the terms and conditions of the Creative Commons Attribution (CC BY 4.0) License.

(c) Articles by the authors; SHST, Cluj-Napoca, Romania. The journal allows the author(s) to hold the copyright/to retain publishing rights without restriction. 